\title{
The Effect of Benchmark, Money Raised, Market Value, and Magnitude of Underpricing Towards Abnormal Return Shares on the Long-Term Performance of Initial Public Offerings in Indonesia
}

\author{
"Rani Eka Arini ${ }^{1}$, Yusuf Iskandar ${ }^{2}$ \\ ${ }^{1}$ Management Study Program, Faculty of Business And Humanities, Nusa Putra University, Indonesia. \\ ${ }^{2}$ Management Study Program, Faculty of Business And Humanities, Nusa Putra University, Indonesia. \\ *Corresponding author. E-mail: rani.eka_mn18@nusaputra.ac.id
}

\begin{abstract}
This research aimed to look into the elements that affect stock irregularity on long-term stock returns after 3 years of IPOs (IPOs). The purposive sampling method was used to choose a sample of non-financial enterprises for this study, including as many as 205 non-financial businesses during the $2010-2020$ period. The analysis was conducted using regression analysis. The findings revealed that all variable independents have a significant relationship with Abnormal Return, The four independent variables can explain 42.1 percent of the variation in the dependent variable. This study can provide information to investor in making stock investment decision.
\end{abstract}

Keywords: Benchmark, Money Raised, Market Value, Magnitude of Underpricing, and Abnormal Return.

\section{INTRODUCTION}

One of the reasons companies choose listings in the primary or secondary markets is the difference of opinion about imperfect capital market integration. By choosing listing in a more integrated market, it is expected that companies committed to improved governance and greater disclosure of information are expected [1].The capital market is seen as one of the most efficient ways to collect funds for development financing by collecting funds from the general public and channeling them to productive sectors. One of the external sources of funds that companies can raise to grow is the issuance of shares [2]. The focus of shares issued in Initial Public Offerings (IPOs) is generally on enormous profit margins for investors in IPOs and huge initial returns in the secondary market [3]. Furthermore, The long-term performance of shares issued is still a source of debate.

The rate of long-term profit from shares sold through the primary market in the international capital market. Ritter's results show that in America, stocks sold through Initial Public Offerings (IPOs) outperform other stocks up to five years after the IPO [6]. Initial Public Offerings (IPOs) reach an average of $29 \%$ less than other stocks three years after the initial market and no less than $50 \%$ in the fifth year. According to one conclusion, the underperformance of shares is influenced by the low volume of stock trading [6]. As a result, the formulation of the problem in this study, based on the introduction above, is what factors determine anomalous stock returns on long-term performance in non-financial companies.

\section{LITERATURE REVIEW}

The level of profit in investment management is called return. A reasonable return if investors expect an inevitable return from the funds that have been invested in investing their capital. Return is the total profit level received by investors during the holding period. It is represented as a percentage of the acquisition price of the investment at the beginning of the holding period. It is essential to distinguish between predicted and actual returns in investment management [3].

Investing in Initial Public Offerings (IPOs) is an excellent method to diversify your portfolio. However, it is a risky approach in the long run due to the low long-term performance of equities after IPOs (longrun underperformance). The decline in performance that occurs in the lon $g$ term will harm investors because because it will get a negative return. 
The tactical approach used is bought and hold [6].

\subsection{Understanding the Capital Market}

Every company needs a financial market or financial market to support its source of funds. The financial market consists of the money market and the capital market. The money market provides short-term funds, while the capital market is concerned with providing long-term funds. The money market is mainly used by banks and a small number of large companies, while the capital market is mainly used by companies to seek large amounts of funds and is used by investors to invest their funds. Thus the capital market can be used as an alternative source of funds for companies and as an instrument for investors [8].

A capital market is a place where long-term financial demand and supply collide. The long-term demand comes from companies that are carried out by issuing long-term financial instruments (securities), such as stocks and bonds. It is long-term because the funds embedded in stocks mean that they will be embedded forever in the company, while bonds generally take at least five years to be repaid [9].

\subsubsection{Strategic Functions of the Capital Market}

The capital market serves a number of strategic functions that make it appealing to individuals in need of cash, those with funds, and the government. As a result, the capital market serves a variety of purposes, including [8] :

1) As a means of raising funds

The company's capital requirements might be satisfied through a variety of ways. The capital market and banking system, which have been known as traditional financial intermediary media, are two sources that corporations might use. As a result, corporations can enter the capital market to raise funds as needed, with no limit on the amount of money they can raise.

2) As a Financial Instrument

Because every investor may easily move their funds from one business to the next or from one industry to another, investing in the capital market is more flexible. As a result, the capital market is an alternative to banks or direct investing for placing cash for investors and investors.

3) Income Equity

If the company does not go public, the company's owners are confined to the company's personal founders. The corporation's decision to go public allows the general public to acquire a piece of the company. Finally, the community can enjoy it, implying that income is distributed evenly among the community.

4) As an investment driver

One of the conducive investment climates is a liquid market for them. More enterprises will enter the capital market as the capital market improves, and more investors, both domestic and foreign, will be prepared to invest their cash in Indonesia through the purchase of securities in the capital market.

\subsubsection{Market Classification}

The sale of shares by companies that go public can be made in various ways according to the type of market and the securities to be sold. These are the markets we're talking about [8]:

1) Primary Market or Primary Market

The primary market offers shares from companies that issue shares or issuers to investors for a time determined by the issuing party before the shares are traded on the secondary market.

2) Market for Used Goods

As described above, after the primary market is completed, followed by the registration of the stock exchange, then investors can sell and buy shares on the stock exchange floor. The sale and purchase of securities carried out on the stock exchange are known as the secondary market.

3) Parallel Exchange or Over The Counter Market

This parallel exchange accommodates companies that cannot enter the stock exchange because the requirements are not met.

\subsubsection{Initial Public Offerings (IPOs)}

The desire for listing continues to grow and become community demands and efforts to minimize risks. The company has decided to sell its shares to the public by the capital market laws and the implementing regulations related to it. It is ready for public valuation in large quantities [10]. To sell its shares on the capital market or stock exchange, the company must go public. In going public, companies need the role of capital market supporting institutions, which will assist companies from providing the documents needed for registration with BAPEPAM to registering their shares on the stock exchange [8].

\subsubsection{Stock}

A stock is a piece of paper that shows investors' rights to get a portion in the organization's prospects 
or assets that issue the securities, as well as the numerous conditions that allow these investors to exercise their rights [9]. Stock prices can be influenced by many factors, both internal (financial performance) and external (fluctuations in the rupiah exchange rate for foreign currencies) [11].

\subsubsection{Abnormal Stock Return Phenomenon}

The difference between the actual return and the expected return causes abnormal returns is [12]. Meanwhile, abnormal return is the discrepancy between actual and predicted profits [9].

\subsubsection{Underperforming Phenomenon}

The phenomenon of long-term underperformance occurs in stocks in the capital market [13]. The factors that can explain the occurrence of underperformance are errors in risk measurement, lousy luck, and investors being too optimistic about the company's prospects [6].Decreasing in performance that occurs in the long term will harm investors because it will get a negative return. The phenomenon of underperformance can be observed in various capital markets around the world [3].

\subsubsection{Long-Term Performance}

Long-term performance is the Stock's performance over more than one year [14]. The underperformance phenomenon in the long-term performance of Initial Public Offerings (IPOs) conducted in Italy. The results obtained on the majority of Initial Public Offerings (IPOs) whose outperformance occurs after 1, 5, and 10 trading days and after 2 or 3 years of trading, there will be a decline in market performance, despite the Return of Initial Public Offerings (IPOs) shares in 1980- an does not show a significant difference compared to other stock returns [14].

\subsection{Factors Affecting Abnormal Return}

\subsubsection{Benchmarks}

The Buy and Hold Abnormal Return is calculated using a benchmark (BHAR). The capital market has many stock transactions from various companies that make up the market portfolio. Investors ' return is called the market index return if they invest in the portfolio market within a certain period (Rmt) [15].

\subsubsection{Money Raised}

Money Raised the number of funds raised in Initial Public Offerings (IPOs). Initial Public Offerings' long-term performance (IPOs) depends on the amount of money (initial proceeds) that increases during Initial Public Offerings (IPOs). Initial proceeds result from multiplying the public offering price of shares with the number of shares issued [15].

\subsubsection{Market Value}

A market value, often known as a market price, is the price of something in the actual world, most manageable price to determine because it is the price of an ongoing stock, or if the market is closed, it can be said that the market is the closing price. (closing price) [16].

\subsubsection{Magnitude of Underpricing}

The magnitude of underpricing is the initial profit (initial return) of the pricing amount. It is pretty reasonable that the amount of the initial profit has an impact on the performance of initial public offerings (IPOs). The difference between the closing share price in the secondary market on the first day minus the initial public offerings (IPOs) divided by the initial share price is the initial return [15]. 


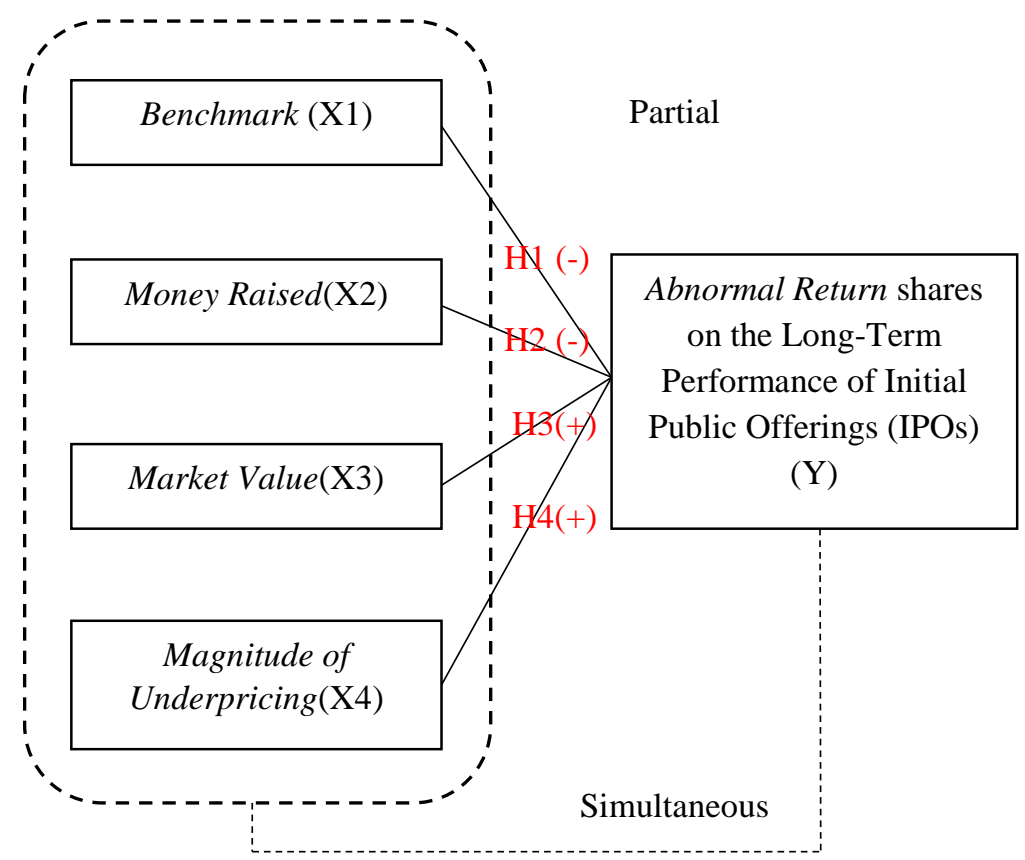

Figure 3. Research paradigm

According to the above-mentioned research paradigm, the study hypothesis is as follows :

H1 : Initial Public Offerings are harmed by benchmarking because extraordinary stock returns on long-term company success are harmed (IPOs).

$\mathrm{H} 2$ : Initial Public Offerings (IPOs) hinder abnormal stock returns on long-term corporate performance (IPOs).

H3 : Anomaly stock returns on long-term company performance are harmed by market value Initial Public Offerings (IPOs).

$\mathrm{H} 4$ : Underpricing has a negative impact on abnormal stock returns based on long-term firm performance Initial Public Offerings (IPOs).

\section{METHODOLOGY}

\subsection{Sampling}

Because the data to be analyzed is the year of the company's Initial Public Offerings (IPOs) plus 36 months after the company's Initial Public Offerings (IPOs), the study's population consists of non-financial enterprises that undertake Initial Public Offerings (IPOs) from 2010 to 2020. (IPOs). In terms of the number of companies, there are 674 in total. Taking samples from the population uses a non-probability sampling technique called purposive sampling, in which the sample is chosen based on defined criteria. The following are the criteria[3]:
1) From 2010 to 2020, all non-financial companies that went public on the Indonesia Stock Exchange.

2) The company's initial public offering (IPO) date is available.

3) Initial offering price and closing price data are available (closing price) at Initial Public Offerings (IPOs) also to twelve months, twentyfour months, and thirty-six months after Initial Public Offerings (IPOs).

4) All non-financial companies in Indonesia provide complete ratios according to the variables studied during the 2010-2020 period and three years after Initial Public Offerings (IPOs).

The following is a sample based on the criteria specified above:

Table 2. Sample Criteria

\begin{tabular}{lll}
\hline No & \multicolumn{1}{c}{ Sample Criteria } & Amount \\
\hline & From 2010 to 2020, all non- \\
& financial companies that went \\
& public on the Indonesia Stock \\
& Exchange. \\
& The company's initial public \\
2 offering (IPO) date on the \\
Indonesia Stock Exchange (IDX) \\
is available.
\end{tabular}




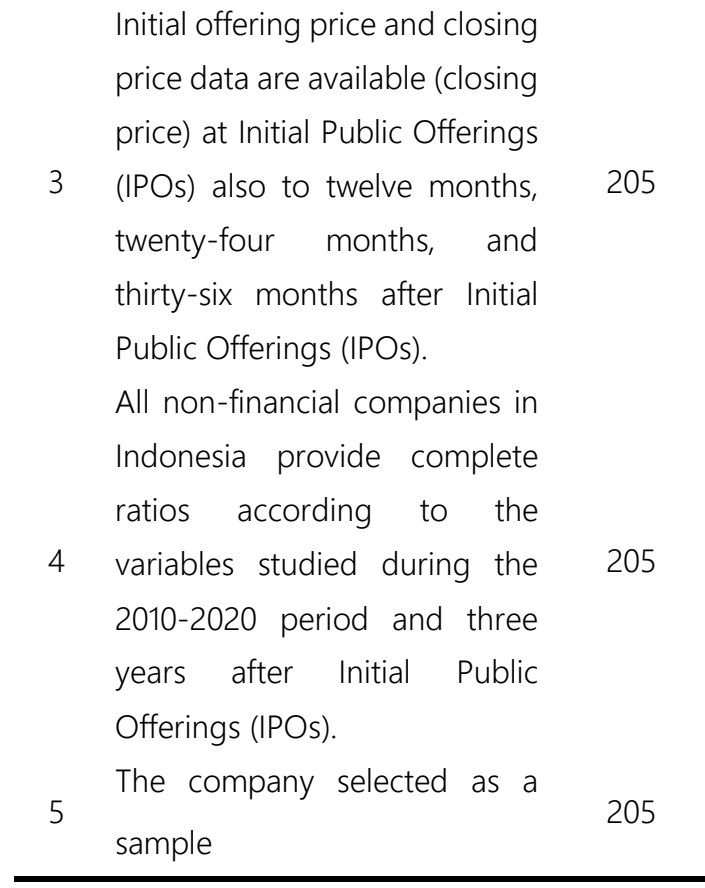

Source: Processed

\subsection{Types and Sources of Data}

\subsubsection{Data Type}

Time series data is a type of secondary data are analyzed in this study for all dependent and independent variables. Secondary data was obtained using the observation method during the research period, namely from 2010 to 2020 .

\subsubsection{Data Source}

For the 2010-2020 timeframe, data was acquired from the Indonesia Stock Exchange (IDX) in the form of IDX Statistics and the Indonesia Capital Market Directory (ICMD), as well as the Yahoo Finance website for non-financial firms.

\subsection{Data Collection Method}

This study makes use of secondary data, which is a type of data that is not collected directly from the source simplifies the data collecting process is through literature study and documentation.

1) Literature Study

The researcher examines the theory obtained from the literature of books, journals, and previous research results to understand the literature that can be used as a theoretical basis.

2) Documentation

Researchers collected and studied data from the Indonesia Stock Exchange (IDX) in the form of IDX Statistics and the Indonesia Capital Market
Directory (ICMD), as well as the Yahoo Finance website for non-financial corporations for the 2010-2020 period, after which it was continued with recording and counting.

\subsection{Data Analysis Method}

Multiple regression analysis was used in this work as a data analysis strategy. The multiple linear regression formula used in this study is:

$$
\mathrm{Y}=\mathrm{a}+\mathrm{b}_{1} \mathrm{X}_{1}+\mathrm{b} 2 \mathrm{X}_{2}+\mathrm{b} 3 \mathrm{X} 3+\mathrm{b} 4 \mathrm{X} 4+\mathrm{e}
$$

Information:

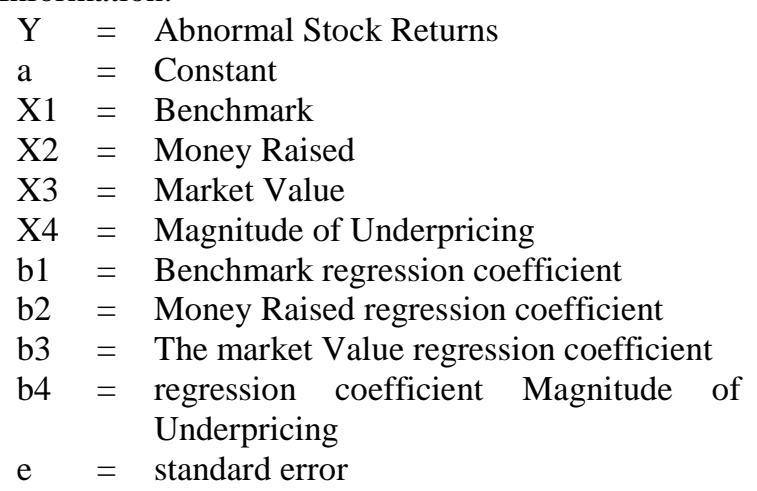

\section{RESULTS AND DISCUSSION}

\subsection{Variable Description}

The average abnormal return in this study was 67.74 with a maximum value of 91.71 at Indah Prakasa Sentosa Tbk (INPS), a minimum value of -16.12 at Northcliff Citranusa Indonesia (SKYB), and the standard deviation of abnormal return values. Shares of 6.69. This shows that the difference between stock returns and market returns in non-financial companies for 2010 to 2020 after 36 months of Initial Public Offerings (IPOs) has the highest abnormal return value of $1475 \%$ above the market return, namely the Multifiling Mitra Indonesia Tbk (MFMI) company. The lowest value of abnormal stock returns is $-155 \%$ below the market return, namely the company Kino Indonesia Tbk (KINO).

The benchmark average in this study has a value of 1.70 with a maximum value of 3.84 for the Kino Indonesia Tbk (KINO) company, the minimum value of 0.22 for the Sky Energy Indonesia Tbk (JSKY) and Jaya Trishindo Tbk (HELI) companies. ) and the standard deviation of the benchmark value is 1.14 . This shows the market index value at 36 months after the IPO divided by the index value when offering to non-financial companies for the 2010 to 2020 period after 36 months. Initial Public Offerings (IPOs) have the highest benchmark of $385 \%$ above the market index value at the time of offering. At the company 
Kino Indonesia Tbk (KINO), while the lowest benchmark value of $-23 \%$ below the market index value at the time of the offering was found in the companies Sky Energy Indonesia Tbk (JSKY) and Jaya Trishindo Tbk (HELI).

The average money raised in this study has a value of 92.56 with a maximum value of 27.56 at the PP Properti Tbk (PPRO) company, the minimum value of 2.69 at the Apexindo Pratama Duta Tbk (APEX) company, and the standard deviation of the value money raised is 26.67 This shows the multiplication of the public offering price with the number of shares issued in non-financial companies for the period 2010 to 2020 after 36 months Initial Public Offerings (IPOs) have the highest money raised of 2.756 in PP Properti Tbk (PPRO) companies, while the lowest value of money raised was 296.44 at Baramulti Suksessarana Tbk (BSSR). The average money raised from all samples had a value of 92.56 .

The average market value in this study is 14.49 , with a maximum value of 5.520 at the Sanurhasta Mitra Tbk (MINA) company, a minimum value of 19.96 at the Apexindo Pratama Duta Tbk (APEX) company, and the standard deviation of the market value. Of 55.41. This shows the multiplication between the market price and the number of shares issued in non-financial companies for 2010 to 2020 after 36 months. Initial Public Offerings (IPOs) have the highest market value of 5,520 at the company Sanurhasta Mitra Tbk (MINA), while the lowest market value is 19.96 at Apexindo Pratama Duta Tbk (APEX), and the average market value of all samples is 14.49 .

The magnitude of underpricing in this study shows the difference between the closing price on the first day of the secondary market and the initial offering price after that divided by the initial offering price into non-financial companies for the period 2006 to 2009 after 36 months of Initial Public Offerings (IPOs) has an average value of $3 \%$ with a maximum value of $6098 \%$ above the initial offering price at the Mitra Pemuda Tbk (MTRA) company, the Mitra Pemuda Tbk (MTRA).

\subsection{Discussion of the Research Findings}

\subsubsection{Classical Assumption Test}

Before performing multiple regression analysis, the data is tested for classical assumptions first. Moreover, it was found that the research data had multicollinearity and autocorrelation disturbances. After that, the classical assumption test was carried out using four independent variables so that it was found that all the classical assumption test requirements were met.
Table 3. Smirnov-Kolmogorov test

\begin{tabular}{llr}
\hline & & \multicolumn{1}{c}{$\begin{array}{r}\text { Unstandardized } \\
\text { Residual }\end{array}$} \\
\hline $\mathrm{N}$ & & 205 \\
\hline Normal & mean & .0000002 \\
\cline { 2 - 3 } Parameters, & Std. Deviation & 2879340568000 \\
& & 000 \\
\hline Most Extreme & Absolute & .160 \\
\cline { 2 - 3 } Differences & Positive & .160 \\
\cline { 2 - 3 } & negative & -129 \\
\hline Test Statistics & & .160 \\
\hline asymp. Sig. (2-tailed) & $.067 \mathrm{c}$ \\
\hline Source: Data processed, IBM SPSS
\end{tabular}

Source: Data processed, IBM SPSS

The Asymp value is shown in table 3. Sig. (2tailed) $=0.067,0.05$, indicating that the data is normally distributed.

After data transformation, the following are the findings of the multicollinearity test:

Table 4. After transformation, perform a multicollinearity test.

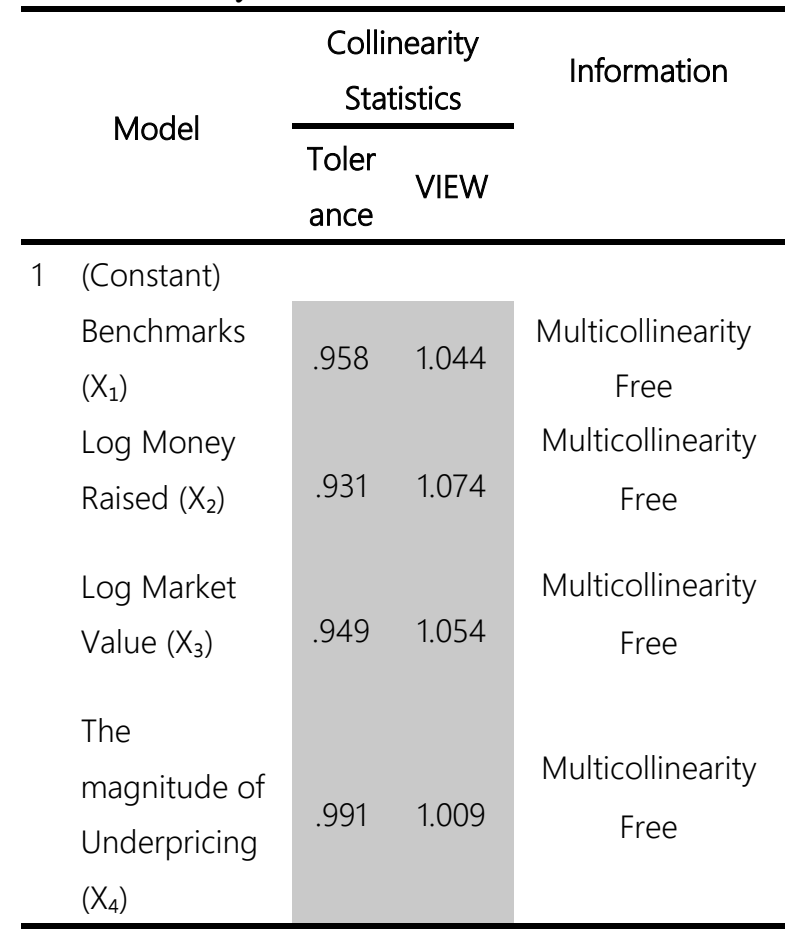

a. Dependent Variable: Abnormal Stock Return (Y) Source: Data processed, IBM SPSS

Table 4 shows that the tolerance value of all independent variables is greater than 0.1 and the VIF 
value is less than 10 , indicating that the four independent variables are free of multicollinearity symptoms.

The following are the results of the autocorrelation using the Durbin-Watson test after data transformation:

Table 5. Autocorrelation test after transformation

\begin{tabular}{lrrr}
\hline Model & R & R Square & Durbin-Watson \\
\hline 1 & $.889^{a}$ & .546 & 1.564 \\
\hline
\end{tabular}

a. Predictors: (Constant), Magnitude of Underpricing $\left(\mathrm{X}_{4}\right)$, Benchmark $\left(\mathrm{X}_{1}\right)$, Log Market Value $\left(\mathrm{X}_{3}\right)$, Log Money Raised $\left(\mathrm{X}_{2}\right)$

b. Dependent Variable: Abnormal Stock Return (Y)

Based on the results of the Durbin-Watson test in Table 5, it shows a value of 1.564 , while in the DW table for " $k "=4$ and $\mathrm{N}=205$, the size of the DW-table: $\mathrm{dL}($ upper limit $)=1.676$ and $\mathrm{dU}($ lower limit $)=1.740$, $4-\mathrm{dU}=1.560$. The DW value is $1.864>$ from the $1.676 \mathrm{dL}$ limit and less than $4-1.560$ (4-dU); it can be concluded that the results of the research data $(1.676<$ $1.564<1.736)$ have no positive or negative autocorrelation. This regression model is appropriate for predicting abnormal stock returns based on the input of the independent variables.

\subsubsection{Model Fit Test Results and Degree}

$$
\text { of Determination }
$$

Table 6. Simultaneous test (F test)

\begin{tabular}{|c|c|c|c|c|c|}
\hline \multicolumn{2}{|c|}{ Model } & \multirow{2}{*}{$\frac{d f}{4}$} & \multirow{2}{*}{$\frac{\text { Mean Square }}{23088021510000}$} & \multirow{2}{*}{$\frac{F}{9.573}$} & \multirow{2}{*}{$\frac{\text { Sig. }}{.000^{\mathrm{b}}}$} \\
\hline 1 & Regres & & & & \\
\hline & sion & & 00000000 & & \\
\hline & Residu & 200 & 8456414150000 & & \\
\hline & al & & 0000000 & & \\
\hline & Total & 204 & & & \\
\hline
\end{tabular}

a. Dependent Variable: Abnormal Stock Return (Y)

b. Predictors: (Constant), Magnitude of

Underpricing $\left(X_{4}\right)$, Benchmark $\left(X_{1}\right)$, Log Market

Value $\left(X_{3}\right)$, Log Money Raised $\left(X_{2}\right)$

Source: Data processed, IBM SPSS

The findings of the regression analysis reveal that the independent factors have a substantial effect on the dependent variable in general. Table 6 shows that the F-value is 9.573 with a $0 \%$ chance of being correct. The regression model may be used to predict dependent variable with a probability of less than $5 \%$, or in other words, independent variables influence the movement of Abnormal Returns of Initial Public Offerings in Long-Term Company Performance (IPOs).

Table 7. Coefficient of Determination Test $\left(\mathrm{R}^{2}\right)$

Adjusted R

\begin{tabular}{lrrr} 
Model & R & R Square & \multicolumn{2}{l}{ Square } \\
\hline 1 & $.689^{a}$ & .497 & .421 \\
\hline
\end{tabular}

a. Predictors: (Constant), Magnitude of

Underpricing $\left(\mathrm{X}_{4}\right)$, Benchmark $\left(\mathrm{X}_{1}\right)$, Log Market

Value $\left(X_{3}\right)$, Log Money Raised $\left(X_{2}\right)$

b. Dependent Variable: Abnormal Stock Return (Y)

In table 7 , the value of $\mathrm{R} 2$ in the Adjusted $\mathrm{R}$ Square column is 0.421 or $42.1 \%$. This means that it shows the ability of the independent variables to explain the dependent variable is $42.1 \%$. In comparison, other variables influence the remaining $57.9 \%$.

\subsubsection{Hypothesis Testing}

Table 8. Partial test (t-test)

\begin{tabular}{|c|c|c|c|c|}
\hline & & Standardized & & \\
\hline & Model & Coefficients & $t$ & Sig. \\
\hline & & Beta & & \\
\hline 1 & (Constant) & & -2.095 & .037 \\
\hline & Benchmarks & -.038 & -.524 & .601 \\
\hline & $\left(X_{1}\right)$ & & & \\
\hline & Log Money & -.034 & .463 & .644 \\
\hline & Raised $\left(X_{2}\right)$ & & & \\
\hline & Log Market & .059 & .047 & .417 \\
\hline & Value $\left(X_{3}\right)$ & & & \\
\hline & Magnitude & .016 & .029 & .819 \\
\hline & of & & & \\
\hline & Underpricin & & & \\
\hline & $g\left(X_{4}\right)$ & & & \\
\hline
\end{tabular}

Source: Data processed, IBM SPSS

Based on table 8 shown above, mathematically, the multiple linear regression equation is obtained with the following results: 


\section{Abnormal $=1,796-0.089$ Benchmark - 0.049 Return Share Money Raised + 0.080 Market Value $+\mathbf{0 . 0 3 3}$ Magnitude of Underpricing $+\mathrm{e}$}

If the independent variable is held constant, the average Abnormal Stock Return is -0.089 , according to the constant of 1.796 . The benchmark regression coefficient is -0.089 , indicating that the benchmark has a negative impact. The Abnormal Return of Stocks will fall by -0.089 if the benchmark increases by $1 \%$, providing all other variables remain constant. Money raised has a regression coefficient of -0.049 , indicating that money raised has a negative impac. If the amount raised rises by $1 \%$, the Abnormal Return will fall by 0.049 , provided all other factors remain constant. The market value regression coefficient is +0.080 , indicating that the market value influences Abnormal Stock Returns. If the market value rises by $1 \%$, the Abnormal Return rises by 0.080 , providing all other variables remain constant. The extent of underpricing has a favorable influence on atypical stock returns on the long-term performance of initial public offerings, with a regression value of +0.033 . (IPOs).

The study's first premise is that the benchmark variable has a negative impact on dependent variable. The findings of 1 of -0.038 show that the benchmark is moving in the wrong direction; the t-count Benchmark value is -0.524 , with a significance value of 0.05 . The findings of 1 of -0.038 show that the benchmark is moving in the wrong direction; the tcount Benchmark value is -0.524 , with a significance value of 0.05 . The Benchmark variable has a significant and negative effect on Abnormal Stock Returns on Long-Term Company Performance Initial Public Offerings, with a significance value of 0.05 .

As a consequence, Hypothesis 1: "Benchmarks reduce abnormal stock returns on long-term firm performance Initial Public Offerings (IPOs)" is accepted. According to research undertaken by [15], the number of companies that perform poorly on the benchmark is always bigger than the number of companies that perform well on the index. It can also be explained by the fact that underperformance is driven by the low volume of trading [6]. Previous study by[3] and [2], which found that the benchmark impacted dependent variable. [2] suggested that the low degree of relevance could be due to investors' lack of responsiveness to each issuer's market performance, implying that the market performance would appear positive when examined by the JCI. However, after looking at each issuer's market performance, the data revealed aberrant stock returns on Long-Term Company Performance. The long-term performance of Initial Public Offerings (IPOs) is negative or declining, probably due to abnormal stock returns on long-term company performance. If there are shares whose prices are indicated below, Initial Public Offerings (IPOs) are determined based on the share price of each issuer. The share price in Initial Public Offerings is shown below (IPOs). Furthermore, there are external considerations as such as IDX policy changes during the study year.

The study's second premise is that aberrant stock returns on the performance of long-term enterprises in initial public offerings are harmed by the moneyraised variable (IPOs). Money raised has a negative direction, according to the results of 1 of -0.034 ; the $\mathrm{t}$ count of money raised is 0.463 , with a significance value of 0.05 . The money-raised variable has a substantial and negative effect on atypical stock returns on the long-term success of initial public offerings, according to a significance value of 0.05 . (IPOs). As a result, Hypothesis 2 is selected, which asserts that "money raised in initial public offerings (IPOs) affects abnormal stock returns on long-term firm performance." The findings of this study, according to research conducted by[2], show that the amount of money received by a company during its initial public offering (IPO) is not a benchmark for investors to invest in, possibly because long-term investors pay less attention to stock price movements that reflect market performance. They are more concerned with the company's actual performance, which reflects the company's intrinsic value, namely high-quality earnings information.

The study's third hypothesis is that the market value variable has a beneficial effect on atypical stock returns on initial public offerings' long-term success (IPOs). The findings of 1 of 0.059 show that the market value is moving in the right way; the market value's t- value is 0.047 , with a significance value of 0.05 . As a result, Hypothesis 3 is accepted, which states that "market value has a favorable effect on abnormal stock returns on long-term company performance Initial Public Offerings (IPOs)." The findings of this study are supported by research [3], which claims that market valuation has a beneficial impact on the success of Initial Public Offerings over time (IPOs). The market value of a firm can be used to estimate its long-term performance by looking at the market share price. Because the stock price describes the company's state, if the stock price in the market improves, the company's performance will improve as well[3]. Previous research[2] found that Market Value had a beneficial effect on Abnormal Stock Returns, which supports the conclusions of this analysis (IPOs). [2] states that a significant positive effect of the market value variable on the increase in abnormal stock returns on the company's long-term performance in initial public offerings (IPOs); this positive relationship is due to the increase in market value, 
which in this case is an increase in stock prices. It will give investors and potential investors an overview of the company's performance and financial situation.

The study's fourth premise is that the magnitude of underpricing has a beneficial impact on atypical stock returns and the long-term performance of initial public offerings (IPOs). The findings of 1 of 0.016 show that the market value is moving in the right way; the market value is 0.029 , with a significance value of 0.05. As a result, Hypothesis 4 is accepted, which states that "the extent of underpricing has a beneficial effect on abnormal stock returns." According to research[3] and [2], the extent of underpricing has a beneficial effect on the long-term performance of Initial Public Offerings (IPOs). This explains why the magnitude of underpricing can have an impact on abnormal stock returns in non-financial companies. The abnormal return value of shares in non-financial enterprises with long-term Initial Public Offerings (IPOs) increases as the magnitude of underpricing increases (overperformed)[3]. The stock price in the secondary market is higher than the price at the time of the initial issue, according to [2]. Underpricing was observed in 205 non-financial companies that issued initial public offerings (IPOs) between 2010 and 2020. Because the money received through Initial Public Offerings (IPOs) were not optimal, this was not profitable. This is very advantageous for investors since they will have the possibility to earn and can be used as investors to retain shares for a long time or sell them quickly to minimize losses.

\section{CONCLUSION}

The findings revealed that partially benchmarking and raising money has a considerable and unfavorable impact on dependent variable. Dependent Variable is influenced by market value and the magnitude of underpricing (IPOs). The sample size used in this study was nevertheless small, with only 205 non-financial organizations included. This study has a small number of variables. At the same time, many other factors, such as the business's age and size, may influence Abnormal Stock Returns. This is because the longer a company has been in operation, the easier it is to predict abnormal stock returns.

This research has several limitations namely:

1) The scope of this study is confined to nonfinancial businesses.

2) The period used in this study is only in the period $2010-2020$.

Suggestions based on the previously mentioned limitations, namely:

1) Using research objects that move in other sectors.
2) Extending the observation period for more, which can later assist researchers in obtaining more accurate and precise research results.

\section{ACKNOWLEDGMENTS}

Alhamdulillah, thanks to Allah SWT, the researcher was able to complete this scientific article because of His will and blessing. Researchers realize that this scientific article will not be finished without prayers, support, and encouragement from various parties. The researcher would want to express himself on this occasion. his gratitude to Yusuf Iskandar, S.Si., MM as the Head of the Management Study Program, Faculty of Business and Humanities, Nusa Putra Sukabumi University, as well as an Advisor Lecturer who has provided direction and motivation in guiding researchers in compiling this scientific article.

\section{REFERENCES}

[1] Suherman, "Long-Term Performance and Post-Ipo Liquidity on the Main Board and Development of the Indonesia Stock Exchange," vol. 19, no. 1, pp. 30-40, 2015.

[2] Moreover, AI Hilal, A, Syafnita, "Factors Influencing Abnormal Returns on Long-Term Performance," J. Eco. and Business, vol. 21, no. September, pp. 73-78, 2018.

[3] MT Abid and H. Muharam, "Analysis Of Factors Affecting Abnormal Stock Return On Long-Term Performance Of Initial Public Offering (IPO) (Case Study on Non-Financial Companies that Go Public on the Indonesia Stock Exchange in 2006-2009)," J. Stud. manage. Organ., vol. 10, no. 2, pp. 167-177, 2013, doi:10.14710/jsmo.v10i2.5915.

[4] R. Subekti and R. Tjitrosudibio, Code of Civil law. Jakarta: Pradnya Paramita, 2001.

[5] . S., "Is the Long-Term Performance of Initial Public Offerings in Indonesia Underperformed?," J. Eco., vol. 21, no. 1, p. 1, 2018, doi:10.24912/Je.v21i1.379.

[6] JR RITTER, "The Long-Run Performance of Initial Public Offerings," J. Finance, vol. 46, no. 1, pp. 3-27, 1991, doi:10.1111/j.15406261.1991.tb03743.x.

[7] D. Kusumawardani, T. Haryanto, W. Wibowo, S. Pengajar, F. Economics, and U. Airlangga, "Economics Magazine Year XVIII, No. August 2, 2008," no. 2, pp. 114132,2008

[8] Sutrisono, FINANCIAL MANAGEMENT 
(Theory Concepts \& Applications), Second. Yogyakarta: Econisia, 2017.

[9] S. Husnan and E. Pudjiastuti, Fundamentals of Financial Management, Seventh. Yogyakarta: UPP STIM YKPN, 2018.

[10] N. Apriliasari, "Differences in Short-Term, Medium-Term and Long-Term Financial Performance in Companies Conducting IPOs," pp. 1-18, 2014.

[11] RE Arin, Y. Iskandar, and HF Ningrum, "Factors Affecting Stock Prices in Financial Sector Companies," J. Proaction, vol. 7, no. 1, pp. 1-15, 2020.

[12] Tiara Dewi Hospital, Muhammad Amir Masruhim, "No Title No Title No Title," Lab. researcher. and Pemb. Trop Pharmacy. Fac. Farms. Univ. Mualawarman, Samarinda, East Kalimantan, no. April, pp. 5-24, 2016.

[13] SJ Permana, "Analysis of Factors Affecting Abnormal Stock Returns in Banking and Insurance Companies Listed on the Indonesia Stock Exchange," Bhishma, vol. 11, no. 1, p. 12, 2017, doi:10.19184/bitmap.v11i1.6205.

[14] MW Yusniar, "Short-Term and Long-Term Stock Price Performance After Initial Public Offering (IPO)," J. Management Insights. Univ. Stomach Mangkurat, vol. 4, no. 3, pp. 187-204, 2016.

[15] W. Bessler and S. Thies, "The long-run performance of initial public offerings in Germany," Manag. Finance., vol. 33, no. 6, pp. 420-441, 2007, DOI: $10.1108 / 03074350710748768$.
[16] IF Leleng, V. Ilat, and H. Wokas, "The Effect of Market Value on Holding Period Shares in Food and Beverages Companies Listed on the Indonesia Stock Exchange 2010-2012," Going Concern J. Ris. Account., vol. 8, no. 3, pp. 306-316, 2014 , doi:10.32400/gc.9.1.25234.2014.

[17] RQ Doeswijk, HSK Hemmes, and RH Venekamp, "25 years of Dutch IPOs: An examination of frequently cited IPO anomalies within main sectors and during hotand cold-issue periods," Economist, vol. 154, no. 3, pp. 405-427, 2006, DOI: $10.1007 / \mathrm{s} 10645-006-9017-\mathrm{y}$. 